Southern Illinois University Carbondale

OpenSIUC

Publications

Department of Plant Biology

$11-2002$

\title{
Genetic Diversity and Competitive Abilities of Dalea Purpurea (Fabaceae) from Remnant and Restored Grasslands
}

Danny J. Gustafson

Southern Illinois University Carbondale

David J. Gibson

Southern Illinois University Carbondale, dgibson@plant.siu.edu

Daniel L. Nickrent

Southern Illinois University Carbondale, nickrent@plant.siu.edu

Follow this and additional works at: http://opensiuc.lib.siu.edu/pb_pubs

(C) 2001 by The University of Chicago.

Published in International Journal of Plant Sciences, Vol. 163, No. 6 (2002).

\section{Recommended Citation}

Gustafson, Danny J., Gibson, David J. and Nickrent, Daniel L. "Genetic Diversity and Competitive Abilities of Dalea Purpurea (Fabaceae) from Remnant and Restored Grasslands." (Nov 2002).

This Article is brought to you for free and open access by the Department of Plant Biology at OpenSIUC. It has been accepted for inclusion in Publications by an authorized administrator of OpenSIUC. For more information, please contact opensiuc@lib.siu.edu. 
Int. J. Plant Sci. 163(6):979-990. 2002.

(C) 2002 by The University of Chicago. All rights reserved.

$1058-5893 / 2002 / 16306-0011 \$ 15.00$

\title{
GENETIC DIVERSITY AND COMPETITIVE ABILITIES OF DALEA PURPUREA (FABACEAE) FROM REMNANT AND RESTORED GRASSLANDS
}

\author{
Danny J. Gustafson, ${ }^{1}$ David J. Gibson, and Daniel L. Nickrent \\ Department of Plant Biology, Southern Illinois University, Carbondale, Illinois 62901-6509, U.S.A.
}

\begin{abstract}
Allozyme and randomly amplified polymorphic DNA (RAPD) analyses were used to characterize the genetic relationships of Dalea purpurea from remnant and restored Illinois tallgrass prairies and a large remnant tallgrass prairie in Kansas. The remnant Illinois populations were less genetically diverse than the restored Illinois populations and the Kansas population. These restored Illinois populations were established with at least two seed sources that were locally collected. There was little population divergence $\left(F_{\mathrm{ST}}=0.042\right)$, which is consistent with other perennial forbs, while the genetic relationships among populations reflected geographic proximity. In a greenhouse competition experiment, differences in performance between seedlings was not related to the remnant or restored status of Illinois populations, but plants from Kansas were significantly smaller than Illinois plants. Genetic diversity and competitive ability were not associated with the size of the original source population. Our data indicate that using multiple local seed sources for restoration projects will maintain the local gene pool while enhancing the regional genetic diversity of this species.
\end{abstract}

Keywords: conservation genetics, local seed source, tallgrass prairie, restoration ecology.

\section{Introduction}

Fragmentation of continuous habitat into smaller and more isolated patches can potentially alter the spatial distribution of genetic diversity (Gilpin and Soule 1986; Lande 1988; Barrett and Kohn 1991; Fenster and Dudash 1994; Fore and Guttman 1996, 1999). Models of the effect of habitat fragmentation on population genetic structure indicate that increased isolation of populations will decrease gene flow and increase genetic differentiation among populations (Templeton et al. 1990; Hanski 1991; Fore and Guttman 1992; Husband and Barrett 1996). Population genetic theory and empirical studies (Newman and Pilson 1997; Saccheri et al. 1998) indicate that long-term population viability is positively related to levels of genetic variation (Barrett and Kohn 1991; Dolan 1994; Knapp and Rice 1996; Linhart and Grant 1996; Knapp and Connors 1999).

Founder effects in newly established populations, accompanied by limited gene flow between populations, may further reduce the genetic variation within a population, thus constraining the adaptive flexibility of the population and potentially contributing to reduction in fitness (Williamson and Werth 1999). For restored populations, long-term fitness may be affected by the choice of local or nonlocal seed, single or multiple sources, native or cultivated varieties, and the resultant adaptability and competitiveness of the seedlings as they establish in the new environment. Crosses among genetically related individuals may result in loss of fitness because of inbreeding depression, while crosses among individuals from ge-

\footnotetext{
${ }^{1}$ Author for correspondence; current address: Department of Biology, University of Pennsylvania, Philadelphia, Pennsylvania 19104, U.S.A.; e-mail dannyg@sas.upenn.edu.
}

Manuscript received March 2002; revised manuscript received June 2002. netically divergent source populations may have reduced fitness because of outbreeding depression (Fenster and Dudash 1994; Gustafson et al. 2001). Furthermore, differences in intraspecific competitiveness among populations may determine the genetic identity of the establishing population (Aarssen and Turkington 1985; Turkington 1994). Thus, an ideal approach for guiding the choice of source populations for plant restoration projects would be to assess the performance of different seed sources in multiple environments across the range of the species. For example, Etterson and Shaw (2001) found that seed production of the native annual legume Chamaecrista fasciculata was dramatically reduced in nonnative populations relative to local populations. Reduced fecundity could influence the genetic variance, inbreeding, and demography of subsequent generations and hence population persistence (Etterson and Shaw 2001). In another study of an annual plant, Newman and Pilson (1997) showed a significant reduction in germination and survivorship rates in experimental populations with a low genetic effective population size $\left(N_{\mathrm{e}}\right)$ relative to populations with a high $N_{\mathrm{e}}$. These studies link the effects of genetic diversity, evolutionary potential, and long-term fitness of annual species in experimentally established populations; however, it is unclear whether these same relationships are observed in perennial species. A better understanding of the interactions among fitness, genetic diversity and similarity, and competitiveness of a perennial plant species would benefit conservation biologists seeking to maintain existing and restore altered natural ecosystems.

The goals of this study were to estimate genetic diversity, genetic relationships, and intraspecific competitive abilities of Dalea purpurea from remnant and restored Illinois tallgrass prairies and Konza Prairie, Kansas. Konza Prairie was included to allow us to compare genetic diversity, genetic similarity, and competitive abilities of $D$. purpurea from a large (3487 ha) 
remnant Kansas prairie to the smaller (0.4-97 ha) Illinois prairies. Dalea purpurea Vent. (purple prairie clover, Fabaceae) was selected as the study species because it is a native perennial diploid $(2 \mathrm{n}=14)$ clover species that occurs in a variety of North American grasslands and has been shown to be a core species in the tallgrass prairie (Great Plains Flora Association 1986; Gibson 1989; Gleason and Cronquist 1991). Genetic diversity and genetic relationships were studied using two different molecular markers, protein (allozyme) electrophoresis and randomly amplified polymorphic DNA (RAPD), which differ in their ability to detect genetic variation. An intraspecific competition experiment was used to determine whether differences in plant performance exist among select populations and whether these differences were associated with genetic diversity estimates. Specifically, we wanted to know whether (1) there were differences in genetic diversity between remnant populations and restored Illinois populations established with multiple local seed sources, (2) the Illinois populations were genetically different from the Kansas population, and (3) intraspecific competitive abilities differed among sources.

\section{Material and Methods}

\section{Sites}

In the past 160 years, the tallgrass prairies of Illinois have been reduced from 8.9 million hectares to less than 1000 hectares (White 1978; Robertson and Schwartz 1994; Robertson et al. 1997; Robertson 2001). The remnant tallgrass prairies are typically small and isolated within agricultural and urban landscapes (Robertson and Schwartz 1994; Robertson 2001). Restored prairies were included in this study to provide baseline population genetic information on recently reestablished populations. Twenty-five of the 30 black soil (tallgrass) prairies listed in the Illinois Department of Natural Resources state database, which constituted $>90 \%$ of the acreage of this prairie type in Illinois in 1995, were surveyed for Dalea purpurea, and it occurred in six sites (Gustafson 2000). In October 1995, seeds were collected from three remnant (Grant Creek Prairie, Gensburg-Markham Prairie, and Pellville Cemetery Prairie) and three restored (Black Hawk State Historical Site, Morton Arboretum, and Mason County State Nursery) prairies. A site was considered to be a remnant if it had never been plowed and if any species enrichment practices were conducted only with seeds originating from that site. The Gensburg-Markham Prairie (Gensburg-Markham, $41^{\circ} 36^{\prime} \mathrm{N}, 87^{\circ} 41^{\prime} \mathrm{W}, 38.5$ ha), designated as a natural area in 1972, is the largest remnant tallgrass prairie in the Chicago area and is managed by Northeastern Illinois University (McFall 1991). The Grant Creek Prairie Nature Preserve (Grant Creek, $41^{\circ} 21^{\prime} \mathrm{N}, 88^{\circ} 11^{\prime} \mathrm{W}, 31.6$ ha) was acquired by the State of Illinois in 1978 and had a history of cattle grazing before 1978 (McFall 1991). The Pellville Cemetery Prairie (Pellville, $40^{\circ} 27^{\prime} \mathrm{N}, 87^{\circ} 55^{\prime} \mathrm{W}, 0.4 \mathrm{ha}$ ) is the smallest of the remnant populations sampled and was managed with periodic mowing until 1989. All three Illinois remnant prairies are now managed with annual or biennial spring burning to suppress woody species encroachment and to encourage prairie species (W. Glass and W. McClain [site managers], personal communication).

The three restored Illinois prairies were each established with seed from remnant populations within $80 \mathrm{~km}$ and have been managed with periodic spring burning (site managers, personal communication). The Schulenberg Prairie at Morton Arboretum (Morton Arboretum, $41^{\circ} 49^{\prime} \mathrm{N}, 88^{\circ} 04^{\prime} \mathrm{W}, 40.5 \mathrm{ha}$ ) is one of the oldest and largest restored tallgrass prairies in Illinois. Restoration of this prairie began in 1962 (finished in 1972) on land that had originally been in row crop production for many years (education coordinator, personal communication). The Black Hawk State Historical Site (Black Hawk, $41^{\circ} 28^{\prime} \mathrm{N}$, $90^{\circ} 35^{\prime} \mathrm{W}, 0.4$ ha) population was established in 1985 (site manager, personal communication) and is the smallest restored population in our study. The Mason County State Nursery (Mason County, $40^{\circ} 19^{\prime} \mathrm{N}, 89^{\circ} 54^{\prime} \mathrm{W}, 97.2$ ha) population was established in the mid-1970s. This population is different from the other restored populations because the primary focus of this site is to produce seed to be used by the Illinois Department of Transportation and the Illinois Heritage Program. Mason County management practices include irrigation and the application of fertilizer to promote seed production in D. purpurea and other native prairie forbs (site manager, personal communication).

To measure the genetic distinctiveness of the Illinois populations, D. purpurea seeds were also collected from one, 004B (55.1 ha), of several watersheds that contained D. purpurea at Konza Prairie Biological Station (Konza Prairie, $39^{\circ} 05^{\prime} \mathrm{N}$, $\left.96^{\circ} 35^{\prime} \mathrm{W}\right)$, Kansas. Since 1979 , this ungrazed watershed has been burned every four years. Konza Prairie is a 3487-ha remnant tallgrass prairie in the Flint Hills of Kansas, ca. 750 km west of the Illinois populations (Knapp et al. 1998).

\section{Plants}

At each site, seeds were collected from 30 randomly selected individuals using the following sampling strategies. In large prairies (Gensburg-Markham, Grant Creek, Konza Prairie), a single transect traversing the population with $20 \mathrm{~m}$ between individual collections. Multiple parallel transects spaced $10 \mathrm{~m}$ apart and $10 \mathrm{~m}$ between each individual collection were used to sample the smaller populations (Morton Arboretum, Pellville, Black Hawk). A bulk seed collection from 100+ plants was provided by Mason County (site manager, personal communication). Bulk seed samples were collected from 50 to 100 individuals in each population and used in the competition experiment.

Seeds were removed from the parent plants, stored on ice, transported to Southern Illinois University, Carbondale, and dry cold stratified at $4^{\circ} \mathrm{C}$ for 4 mo. Seeds from the individual collections were scarified and germinated in petri dishes on moistened filter paper, and one randomly selected seedling from each maternal plant was potted in a $16.5-\mathrm{cm}$-diameter pot containing a commercial soilless media (Promix-HP, Hummert International, Earth City, Mo.) and grown in a greenhouse. Ambient lighting in the greenhouse was supplemented with standard grow lamps from 0700 to 1900 hours. Plants were watered as needed and fertilized with $350 \mathrm{mg} \mathrm{m}^{-2}$ of Peter's Fertilizer (N: P:K, $20: 20: 20)$ every 3 wk. Seeds from each bulk collection were scarified, thoroughly mixed, sown into flats, and grown in the greenhouse as described. 


\section{Allozyme Electrophoresis}

Approximately $1.0 \mathrm{~g}$ of fresh leaf tissue from each 2-moold seedling was homogenized in the Tris- $\mathrm{HCl}$ extraction buffer of Wendel and Weeden (1989), placed in 1.5-mL microcentrifuge tubes, and centrifuged at $10,000 \mathrm{rpm}(12,000 \mathrm{~g})$ for $15 \mathrm{~min}$. The supernatant was stored frozen $\left(-80^{\circ} \mathrm{C}\right)$ until needed. Enzyme separation was accomplished using 13\% w/v starch gel (Starch Art hydrolized potato starch, Smithville, Tex.). Five enzyme systems coding for nine putative loci were resolved and selected for use in this study. Enzymes were assayed using two gel/electrode buffer systems: (A) Tris EDTA borate pH 8.0 (Wendel and Weeden 1989) and (B) Ridgeway pH 8.1 (Ridgeway et al. 1970). Enzyme staining protocols were essentially as reported in Wendel and Weeden (1989). The following enzyme systems (with locus abbreviations, enzyme commission numbers, and buffer systems in parentheses) were used: aspartate amino transferase (AAT-2, 2.6.1.1, A), glucose phosphate isomerase (GPI-1 and 2, 5.3.1.9, B), phosphoglucomutase (pgm-2, pgm-3, 2.7.5.1, B), 6-phosphogluconate dehydrogenase (6PGD-1 and 2, 1.1.1.44, A), and triose phosphate isomerase (TPI-1 and 2, 5.3.1.1, A). Genetic interpretation was based on electrophoretic patterns and known enzyme subunit structure and intercellular compartmentalization (Kephart 1990). Alleles with the greatest mobility were designated as $a$, the following ones $b, c$, etc. In addition to alphabetic genotypes (e.g., $a a, a b, b b$ ), the number of multilocus genotypes for each individual and allele frequencies for each locus and for all populations were calculated (table A1).

\section{RAPD Profiling}

To obtain genomic DNA, fresh leaf tissue $(0.1 \mathrm{~g})$ from 1mo-old seedlings was ground to a powder in liquid nitrogen, $1.3 \mathrm{~mL}$ of $94^{\circ} \mathrm{C}$ CTAB buffer $(100 \mathrm{mM}$ Tris- $\mathrm{HCl}, 1.4 \mathrm{M} \mathrm{NaCl}$, $30 \mathrm{mM}$ EDTA, 2\% (w/v) cetyltrimethylammonium bromide [CTAB]) was added, and grinding was continued. Three units of Protease $\mathrm{K}$ and $60 \mu \mathrm{L}$ dithiotreitol $(0.5 \mathrm{M})$ were added and mixed, and the extract transferred to a $2.0-\mathrm{mL}$ microfuge tube and incubated for $30 \mathrm{~min}$ at $45^{\circ} \mathrm{C}$. The sample was extracted with chloroform : isoamyl alcohol $(24: 1)$ and centrifuged at $10,000 \mathrm{rpm}$ for $15 \mathrm{~min}$ at $4^{\circ} \mathrm{C}$. The aqueous layer was transferred to a $1.5-\mathrm{mL}$ microfuge tube, $0.5 \mathrm{~mL}$ of $-20^{\circ} \mathrm{C}$ isopropanol was added and mixed, and the sample was stored in a $-20^{\circ} \mathrm{C}$ freezer for $30 \mathrm{~min}$. The DNA was pelleted, air-dried, and resuspended in $300 \mu \mathrm{L}$ of TE buffer $(1 \mathrm{mM}$ Tris- $\mathrm{HCl}, 0.1$ $\mathrm{mM}$ EDTA); $200 \mu \mathrm{L}$ of $4 \mathrm{M}$ ammonium acetate and $1.0 \mathrm{~mL}$ of $-20^{\circ} \mathrm{C} 100 \%$ ethanol were added; and the sample was stored at $-20^{\circ} \mathrm{C}$ for $60 \mathrm{~min}$. The DNA was pelleted, air-dried, and dissolved in $100 \mu \mathrm{L}$ of TE buffer with RNase (one unit). The DNA concentration of each sample was quantified by comparing to a standard of known concentration on agarose gels stained with ethidium bromide. The genomic DNA was diluted to a working concentration of ca. $5 \mathrm{ng} \mu \mathrm{L}^{-1}$.

Thirty 10-base oligonucleotide primers (Operon Technologies) were surveyed, and six were selected that showed intense and reproducible bands. The following primers (with sequence and number of bands scored in parentheses) were used: A-04 (dAATCGGGCTG, 5), B-07 (dGGTGACGCAG, 3), B-12 (dCCTTGACGCA，4), B-18 (dCCACAGCAGT, 7), N-13 (dAGCGTCACTC, 5), and L-12 (dGGGCGGTACT, 4). Am- plification reactions were performed in $25-\mu \mathrm{L}$ volumes containing $10 \mathrm{mM}$ Tris- $\mathrm{HCl}(\mathrm{pH} 9.0), 50 \mathrm{mM} \mathrm{KCl}, 0.1 \%$ Triton $\mathrm{X}-100,1.2 \mathrm{mM} \mathrm{MgCl} 2,0.2 \mathrm{mM}$ of each dNTP (Pharmacia), $20 \mathrm{ng}$ of primer, $0.2 \mu \mathrm{L}$ Taq polymerase (Promega), and ca. 5 ng of template DNA. One negative control, containing all of the amplification reagents and no template DNA, was run with each reaction. Samples were overlaid with $30 \mu \mathrm{L}$ of mineral oil. Amplifications were performed in a Stratagene Robocycler (model 400860, Stratagene, La Jolla, Calif.) programmed with these parameters: $94^{\circ} \mathrm{C}$ for $3 \mathrm{~min}$, followed by 45 cycles of $94^{\circ} \mathrm{C}$ for $1 \mathrm{~min}, 36^{\circ} \mathrm{C}$ for $1 \mathrm{~min}, 72^{\circ} \mathrm{C}$ for $2 \mathrm{~min}$, and a final incubation at $72^{\circ} \mathrm{C}$ for $10 \mathrm{~min}$. Amplification products $(5 \mu \mathrm{L})$ were electrophoresed in $1.0 \%$ TBE $(0.089 \mathrm{M}$ Tris, $0.089 \mathrm{M}$ boric acid, $0.002 \mathrm{M}$ EDTA) agarose gels. After the dye migrated $15 \mathrm{~cm}$, gels were stained with ethidium bromide, scanned, and stored as digitized image files with a Gel-doc 1000 system (BioRad Laboratories, Hercules, Calif.). The Molecular Analyst (BioRad Laboratories) software package was used to adjust the contrast, thus enhancing the visualization of the DNA bands. A DNA molecular mass marker (Promega, G1741) was used to standardize band intensities and to estimate the size of the RAPD bands. If cross contamination was indicated, with the presence of amplification products in the negative control lane, the run was repeated. The presence or absence of 28 intense and reproducible bands constituted the genotype score for each individual.

\section{Competition Experiment}

A greenhouse competition experiment using a diallel design (Gibson et al. 1999) was used to test for differences in competitive abilities among pairs of seedlings from two remnant Illinois populations (Gensburg-Markham, Pellville), two restored Illinois populations (Black Hawk, Mason County), and the remnant Kansas (Konza Prairie) population. This experiment consisted of two plants per pot with all combinations of the five populations and six replicates per combination. One plant was designated as the target and the other the associate for the purpose of measurements and analyses. Five-week-old seedlings of approximately the same size were planted equal distances from each other and the side of a 16.5 -cm-diameter pot containing commercial soilless media (Promix-HP) and watered as needed. A settling period of $14 \mathrm{~d}$ was allowed for the replacement of dead seedlings, with the experiment starting April 7, 1996. The plants were harvested after $99 \mathrm{~d}$ and dried at $80^{\circ} \mathrm{C}$ for $48 \mathrm{~h}$, and then final biomass (total, shoot, root, inflorescences) was determined. Maximum plant height was measured at 7-d intervals throughout the experiment, but these data are not presented here because the final harvest data reflect the same relationships among populations as did the temporal height data. Nitrogen-fixing Rhizobium inoculum was not included in the experimental design; however, nodules were present, but not quantified, on each individual plant (Gustafson 2000).

A greenhouse intraspecific competition experiment lacks the realism of abiotic factors, the plant-soil community, and plantherbivore interactions that could influence plant population dynamics under field conditions. If, however, a phenomenon is observed under the highly controlled greenhouse conditions, then it is likely to be important in natural populations (Gibson 
et al. 1999; Gibson 2002). Seedling competition experiments with long-lived perennials may not reflect competitive interactions in established populations; however, seedling performance during one growing season can be informative considering that all the restored populations in this study were established with seed (Gustafson 2000).

\section{Data Analysis}

For each population, number of individual plants sampled $(N)$, mean number of alleles per locus $(A)$, percent polymorphic loci $(P)$, mean observed heterozygosity $\left(H_{\text {obs }}\right.$, direct-count estimate), mean Hardy-Weinberg expected heterozygosity $\left(H_{\text {exp }}\right.$, unbiased estimate), and Wright's $F$ statistics were computed using BIOSYS-1 (Swofford and Selander 1981). Chi-square analysis was used to test for Hardy-Weinberg equilibrium goodness of fit for the entire data set and each population using the computer program TFPGA (Miller 1997). An inbreeding coefficient representing the fractional reduction in heterozygosity relative to a random-mating population, with the same allele frequencies, was calculated as $F=\left(H_{\exp }-\right.$ $\left.H_{\text {obs }}\right) / H_{\exp }$ (Swofford and Selander 1981; Hartl and Clark 1997). Linear regression was used to model the relationship between the number of individuals sampled within a population and the inbreeding coefficient $(F)$. For the RAPD analysis, three to seven intense and reproducible bands from six primers were scored for each individual. The percent polymorphic bands $(\mathrm{PB})$ and the number of different multiband phenotypes (MBP) within a population were used as descriptive measures of diversity (Ellstrand and Roose 1987; Jonsson et al. 1996). Genetic variation (both allozyme and RAPD) was apportioned within and among populations using Shannon's diversity, $H^{\prime}=-\Sigma p_{i} \log _{2} p_{i}$, where $p_{i}$ is the frequency of the band (Lewontin 1972; King and Schaal 1989; Gustafson et al. 1999). This measure is appropriate for qualitative data, can be decomposed into nested hierarchical levels, and is relatively insensitive to the dominant inheritance of the RAPD marker (Dawson et al. 1995).

Relationships among populations, based on allozyme and RAPD frequency data, were investigated using principal component analysis (PCA) and parallel analysis (PA) to establish which PCA axes were appropriate for interpretation (SAS Institute 1989). Parallel analysis was used to derive the 95th percentile eigenvalues for each successive PCA axis, based on Monte Carlo analysis of Longman et al.'s (1989) regression equations. Only axes with eigenvalues greater than the PA eigenvalues were retained for interpretation (Franklin et al. 1995). Mantel's test was used to test for an association between the Euclidean distance (allozyme and RAPD) and geographic distance $(\mathrm{km})$ between populations, with comparisons among the Illinois populations and among all populations (McCune 1995). This procedure used a Monte Carlo randomization test (1000 iterations), which calculates the standardized Mantel's statistic $(Z)$ of the observed data and the probability of exceeding this value by random chance. The null hypothesis for this test was that the degree of genetic similarity between pairs of populations and the distance between them were not related.

The populations used in the competition experiment were not randomly selected, and so the target and associate treat- ments (populations) were treated as fixed effects. Final biomass (total, shoot, root, inflorescences) data were analyzed with a two-way ANOVA. This experiment was not a full factorial design and therefore it was not possible to test for target by associate interactions. In the event of significant main effects, Tukey's honest significant difference means separation procedure was used to test for differences among means. When the data did not conform to normality or equal variances, logarithm and square root transformations were performed. Pearson's correlation analysis was used to test for associations between plant performance, genetic diversity measures, and the area of the site. All competition experiment analyses were performed using SYSTAT (Wilkinson 1996).

\section{Results}

\section{Patterns of Genetic Diversity}

There were no fixed allelic differences among the populations; however, Black Hawk (AAT-2, B allele, 8.3\%), Grant Creek (PGM-3, C allele, 2.2\%), and Konza Prairie (PGM-2, $\mathrm{C}$ allele, and PGM-3, B allele, both at 3.8\%) populations had unique alleles at low frequencies (table A1). The mean number of allozyme alleles per locus ranged from 1.3 (Pellville and Gensburg-Markham) to 1.7 (Konza Prairie). Remnant and restored Illinois populations averaged fewer alleles per locus than the Konza Prairie (Kansas) population (table 1). Percent polymorphic loci ranged from $11.1 \%$ to $33.3 \%$, with the restored populations $(29.6 \%)$ averaging higher values than the remnant $(18.5 \%)$ Illinois populations (table 1$)$. Observed heterozygosity estimates ranged from 0.047 to 0.089 , and two of the remnant populations had the lowest while two restored populations had the highest heterozygosity. Two loci (AAT-2, $\chi^{2}=61.6, \mathrm{df}=1, P<0.001 ;$ TPI-1, $\chi^{2}=140, \mathrm{df}=1, P<$ $0.001)$ deviated significantly from Hardy-Weinberg equilibrium at the species level, while Black Hawk (AAT-2, $\chi^{2}=$ 7.3, df $=1, P<0.01$ ), Morton Arboretum (TPI-1, $\chi^{2}=20$, $\mathrm{df}=1, P<0.0001$; TPI-2, $\chi^{2}=8.2$, df $\left.=1, P<0.001\right)$, and Gensburg-Markham (TPI- $1, \chi^{2}=20, \mathrm{df}=1, P<0.0001$ ) had significant deviations within populations. Wright's $F$ statistics indicate little population differentiation $\left(F_{\mathrm{ST}}=0.055\right)$ and low levels of inbreeding $\left(F_{\mathrm{IS}}=0.120\right)$ for the seven populations sampled. However, inbreeding estimates of the fractional reduction in heterozygosity relative to a random-mating population, with the same allele frequencies, indicate a $28 \%$ reduction in the remnant Gensburg-Markham and a $40 \%$ reduction in the restored Morton Arboretum populations (table 1). There was no linear relationship between inbreeding and sample size $\left(F=0.50-0.019\right.$ [sample size], $r^{2}=0.134$, $P=0.42, \mathrm{df}=1,5)$. Shannon's diversity was used to partition genetic variation among populations. At the species level, $77 \%$ of the allozyme variation was partitioned within and $23 \%$ among Dalea purpurea populations. There was no difference in the distribution of genetic variation among the populations within the remnant and restored categories. There was no significant correlation between the allozyme diversity estimates and the area of the site.

All 140 individuals sampled in the allozyme analysis were also used in the RAPD study. The percent polymorphic bands (PB) ranged from $78.6 \%$ (Mason County) to 100\% (Grant 
Table 1

Estimates of Genetic Variation at Nine Allozyme Loci in Seven Populations of Dalea purpurea Sampled in 1995

\begin{tabular}{|c|c|c|c|c|c|c|c|}
\hline Population & $N$ & $A$ & $P$ & $H_{\text {obs }}$ & $H_{\text {exp }}$ & $F$ & $H^{\prime}$ \\
\hline \multicolumn{8}{|l|}{ Illinois: } \\
\hline \multicolumn{8}{|l|}{ Remnant: } \\
\hline Pellville & 26 & $1.3(0.2)$ & 11.1 & $0.047(0.042)$ & $0.046(0.042)$ & -0.022 & 0.12 \\
\hline Grant Creek & 23 & $1.4(0.2)$ & 11.1 & $0.063(0.048)$ & $0.054(0.039)$ & -0.165 & 0.15 \\
\hline Gensburg-Markham & 20 & $1.3(0.2)$ & 33.3 & $0.056(0.035)$ & $0.078(0.041)$ & 0.282 & 0.19 \\
\hline Mean & & 1.3 & 18.5 & 0.055 & 0.059 & 0.032 & 0.15 \\
\hline \multicolumn{8}{|l|}{ Restored: } \\
\hline Black Hawk & 18 & $1.6(0.2)$ & 22.2 & $0.080(0.060)$ & $0.090(0.059)$ & 0.111 & 0.24 \\
\hline Mason County & 20 & $1.4(0.2)$ & 33.3 & $0.089(0.065)$ & $0.091(0.068)$ & 0.022 & 0.23 \\
\hline Morton Arboretum & 20 & $1.4(0.2)$ & 33.3 & $0.061(0.055)$ & $0.102(0.057)$ & 0.401 & 0.26 \\
\hline Mean & & 1.5 & 29.6 & 0.085 & 0.094 & 0.178 & 0.24 \\
\hline \multicolumn{8}{|l|}{ Kansas: } \\
\hline Konza Prairie & 13 & $1.7(0.3)$ & 11.1 & $0.068(0.041)$ & $0.081(0.054)$ & 0.160 & 0.23 \\
\hline Species mean & & 1.5 & 19.7 & 0.073 & 0.074 & 0.123 & 0.21 \\
\hline
\end{tabular}

Note. $N=$ sample size, $A=$ mean number of alleles per loci, $P=$ percent polymorphic loci, $H_{\text {obs }}=$ observed heterzygosity, $H_{\text {exp }}=$ expected heterozygosity, $F=$ inbreeding coefficient, and $H^{\prime}=$ Shannon's diversity. Numbers in parentheses are standard errors.

Creek) (tables 2, A2). The remnant populations averaged $94.1 \% \mathrm{~PB}$, while the average of the restored Illinois populations was lower at $88.0 \% \mathrm{~PB}$. The Konza Prairie, at $86 \% \mathrm{~PB}$, was lower than five of the six Illinois populations sampled (table 2). The multibanding phenotype (MBP) profiles were unique for every individual (table 2). The distribution of RAPD marker variation was found mostly within populations $(86 \%)$ and less among $(14 \%)$ populations. Unlike the allozyme data, there was a difference in the distribution of RAPD variation within the remnant and restored categories. For remnant populations, $91 \%$ of the variation was partitioned within and $9 \%$ among populations, while the restored populations possessed $86 \%$ of the variation within and $14 \%$ among populations. RAPD diversity estimates were not correlated with size of the site.

\section{Population Relationships}

Population relationships were investigated using PCA, with allele frequency or RAPD band frequency data. Parallel analysis of the allozyme and RAPD data indicated that the first two axes were statistically significant and appropriate for interpretation.

The first two axes of the allozyme PCA accounted for $63 \%$ of the variance, with the first axis accounting for $40 \%$ (eigenvalue $=6.4$ ) and the second axis for $23 \%$ (eigenvalue $=3.9$ ) of the variance in the correlation matrix. PCA of the allozyme data revealed predictable associations, with the six Illinois populations different from Konza Prairie (fig. 1A). Within Illinois, the remnant Gensburg-Markham population associated with the restored Morton Arboretum population. The remaining Illinois populations formed two associations, with two remnant (Pellville and Grant Creek) and two restored (Black Hawk and Mason County) populations grouping together (fig. $1 A$ ).

The first two axes of the RAPD PCA accounted for $59 \%$ of the variance with axis 1 (eigenvalue $=10.9$ ) and axis 2 (eigenvalue $=5.7$ ) accounting for $39 \%$ and $20 \%$ of the variance, respectively (fig. $1 B$ ). As with the allozyme PCA results, the Konza Prairie population was different from the six Illinois populations (fig. 1B). The relationships among populations within Illinois were not consistent with the allozyme analysis.

Mantel's test was used to test for significant associations between genetic similarity and geographic distance between populations. There was a significant association $(Z=0.625$, $P<0.05)$ between Euclidean distance and geographical distance among the six Illinois populations using allozyme data, but no significant association $(Z=-0.001, P=0.56)$ with RAPD data. There was no significant association when the Konza Prairie population was included in either the allozyme or RAPD analyses.

\section{Competitive Abilities}

The competition experiment consisted of all pairwise combinations of two remnant (Pellville and Gensburg-Markham)

Table 2

RAPD Analysis of Seven Dalea purpurea Populations Sampled in 1995

\begin{tabular}{|c|c|c|c|c|}
\hline Population & $N$ & MBP & PB & $H^{\prime}$ \\
\hline \multicolumn{5}{|l|}{ Illinois: } \\
\hline \multicolumn{5}{|l|}{ Remnant: } \\
\hline Pellville & 26 & 26 & 89.3 & 1.05 \\
\hline Grant Creek & 20 & 20 & 100.0 & 1.22 \\
\hline Gensburg-Markham & 20 & 20 & 92.9 & 1.12 \\
\hline Total or mean & 66 & 66 & 94.1 & 1.13 \\
\hline \multicolumn{5}{|l|}{ Restored: } \\
\hline Black Hawk & 23 & 23 & 89.0 & 1.07 \\
\hline Mason County & 21 & 21 & 78.6 & 0.98 \\
\hline Morton Arboretum & 21 & 21 & 96.4 & 1.21 \\
\hline Total or mean & 65 & 65 & 88.0 & 1.09 \\
\hline \multicolumn{5}{|l|}{ Kansas: } \\
\hline Konza Prairie & 18 & 18 & 86.0 & 1.12 \\
\hline Species total or mean & 149 & 149 & 89.4 & 1.11 \\
\hline
\end{tabular}

Note. $\quad N=$ sample size, $\mathrm{MBP}=$ multibanding phenotypes, $\mathrm{PB}=$ percent polymorphic bands, and $H^{\prime}=$ Shannon's diversity. 


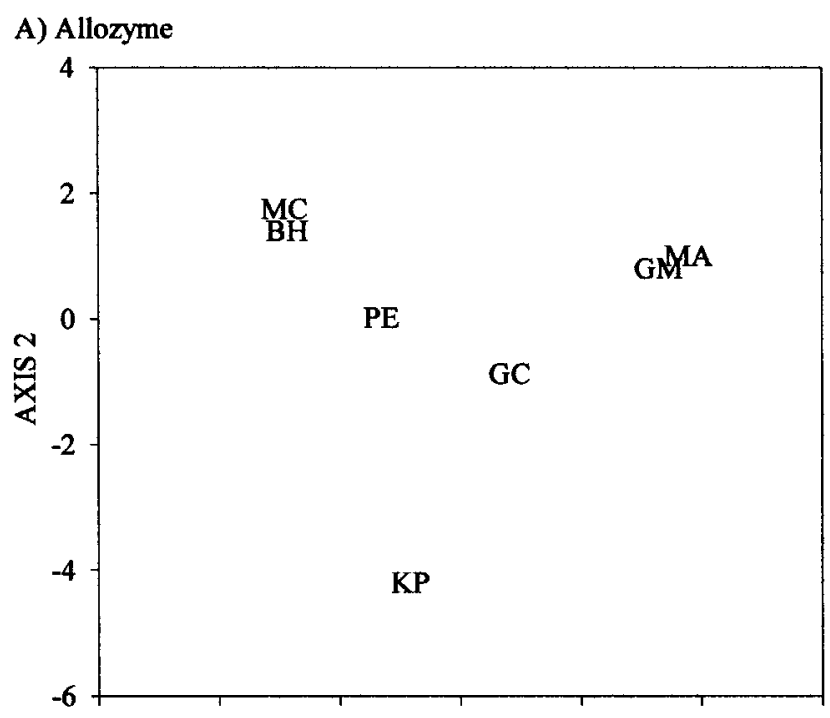

B) RAPD

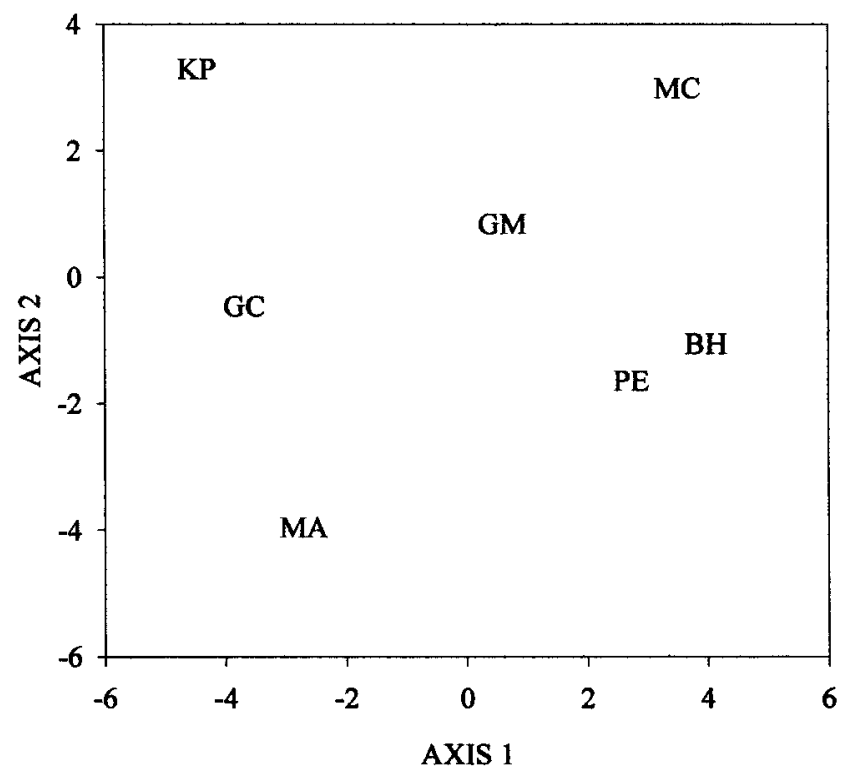

Fig. 1 Principal component analysis depicting the relationships among Dalea purpurea populations from three remnant (Pellville [PE], Grant Creek [GC], and Gensburg-Markham $[G M])$ and three restored (Black Hawk $[B H]$, Mason County $[M C]$, and Morton Arboretum $[M A])$ Illinois populations and Konza Prairie $(K P)$, Kansas, sampled in 1995, based on $(A)$ allozyme and $(B)$ RAPD frequency data.

and two restored (Black Hawk and Mason County) Illinois populations and a Konza Prairie, Kansas, population. Analysis of the final dry biomass (total, shoot, root, inflorescences), height, and number of inflorescences indicated a significant $(P<0.01)$ target main effect, but no effect of the associate plant source population (table 3 ). Pellville plants were significantly taller than the Gensburg-Markham plants, with the plants from the two restored populations (Black Hawk and Mason County) intermediate (fig. 2). The Konza Prairie plants were shorter than plants from all four Illinois populations (fig. 2).
Pellville and Black Hawk plants produced more inflorescences than the Konza plants, and Gensburg-Markham and Mason County plants produced an intermediate number. All four Illinois populations produced significantly larger amounts of mean dry biomass (total, shoot, root, and inflorescences) than the Konza Prairie plants (fig. 2). There was a significant negative correlation between the mean number of inflorescences produced $\left(r^{2}=-0.876, P<0.05\right)$ and the geographic area of the source population. Plants from the two smallest source populations (Pellville and Black Hawk, both 0.4 ha) produced more inflorescences than the larger Mason County (97.2 ha) and Konza Prairie (55.1 ha). There were no associations $(P>0.05)$ among the genetic diversity measures and mean height, biomass (total, shoot, root, inflorescences), and number of inflorescences in the competition experiment.

\section{Discussion}

\section{Patterns of Genetic Diversity}

Dalea purpurea has lower levels of genetic diversity than reported for other members of the Fabaceae (Hamrick and Godt 1989, 1997) but comparable to those of the federally endangered cedar glade endemic Dalea foliosa (Gray) Barneby (Wiltshire 1991). The similarity in genetic diversity to the rare congener is surprising because $D$. purpurea is a widely distributed species (Gleason and Cronquist 1991) and a signifcant component of the tallgrass prairie community (Gibson 1989; Collins and Glenn 1991). The restored populations had $13 \%-38 \%$ higher allozyme diversity estimates relative to the remnant populations, which is likely a result of establishment with seed from multiple source populations. These results are consistent with allozyme studies of restored populations of other species (Gustafson 2000) and theoretical predictions (Knapp and Dryer 1997; Montalvo et al. 1997; Lesica and Allendorf 1999). Gensburg-Markham (remnant) and Morton Arboretum (restored) populations showed evidence of nonrandom mating, which is interesting because the GensburgMarkham population is within the "local" area in which seeds were collected from remnant grasslands and used to establish the Morton Arboretum population. The relatively high diversity estimates in the small remnant population indicates that small isolated remnant populations can contribute to the overall diversity of the species and are potential seed sources for future restoration projects.

The remnant population from Konza Prairie (Kansas) had equal or higher diversity estimates than the remnant Illinois populations for four of the five diversity measures. The three Illinois remnants were small $(0.4,31.5$, and 38.5 ha) and contained only one D. purpurea population at each site (D. J. Gustafson, personal observation), whereas the Konza Prairie 004B watershed is larger (55.1 ha) than the Illinois sites, and there are multiple watersheds containing $D$. purpurea populations within the 3487-ha area of Konza Prairie (Gibson 1989). The Illinois populations exist in a landscape of agricultural fields and urban development, making gene flow (via seed or pollen) among such widely spaced populations unlikely. At Konza Prairie, D. purpurea is an intermediate or core species, according to the core-satellite species hypothesis, with a frequency in $10-\mathrm{m}^{2}$ sample plots of $50 \%-100 \%$ depending 
Table 3

Summary ANOVA Results of a Dalea purpurea Greenhouse Experiment (1996) Examining Competitive Differences in Mean Height, Number of Inflorescences, and Biomass (Total, Shoot, Root, Inflorescences) among Two Remnant and Two Restored Illinois Populations and One Kansas Population

\begin{tabular}{|c|c|c|c|c|c|c|c|}
\hline \multirow[b]{2}{*}{ Source } & \multirow[b]{2}{*}{ df } & \multirow[b]{2}{*}{ Height } & \multirow[b]{2}{*}{ Inflorescences } & \multicolumn{4}{|c|}{ Dry biomass } \\
\hline & & & & Total & Shoot & Root & Inflorescences \\
\hline Target & 4 & $617^{*}$ & $34^{*}$ & $3116^{*}$ & $3244^{*}$ & $1677^{*}$ & $2916^{*}$ \\
\hline Associate & 4 & 227 & 9 & 170 & 102 & 640 & 847 \\
\hline Error & 70 & 104 & 7 & 390 & 379 & 464 & 380 \\
\hline
\end{tabular}

Note. Values are mean squares.

${ }^{*} P \leq 0.01$.

on the management treatment (Gibson 1989; Collins and Glenn 1991). Overall, plant abundance and genetic diversity estimates of $D$. purpurea at Konza Prairie are consistent with predictions for a landscape-scale metapopulation maintained through frequent local gene flow. Additional genetic and demographic studies of core, intermediate, and satellite species within native and disturbed landscapes are needed to comprehensively test such theoretical predictions of the metapopulation model (Hanski 1991; Husband and Barrett 1996; Fore and Guttman 1999).

The diversity estimates based on RAPD analysis, although using the same populations and $98 \%$ of the same individuals as sampled for allozymes, did not show the same pattern of diversity as the allozyme analysis. Remnant populations averaged higher $\mathrm{PB}(94.1 \%)$ than the restored populations $(88.0 \%)$, as did Shannon's diversity measures. The difference between allozyme and RAPD diversity estimates may reflect differences in the two methods to detect fine-scale genetic differences. For example, allozyme markers identify 21 unique multilocus phenotypes (allozyme fingerprints) out of 140 individuals sampled, while the RAPD markers identified 149 unique multibanding phenotypes (RAPD fingerprints) out of the 149 individuals sampled.

The distribution of genetic variation was consistent with other outcrossing perennial herbaceous species with little population divergence $\left(F_{\mathrm{ST}}=0.042\right)$. Shannon's diversity $\left(H^{\prime}\right)$ was used to partition variation into nested hierarchical levels, for both allozyme and RAPD data. Most of the variation was retained within (allozyme $=77 \%$, RAPD $=86 \%$ ) and less among (allozyme $=23 \%$, RAPD $=14 \%$ ) populations. These results are consistent with other allozyme and RAPD studies of outcrossing perennial species (Hamrick 1989; Hamrick and Godt 1989, 1997; Dolan 1994; Huff et al. 1993, 1998; Huff 1997; Gustafson et al. 1999, 2001; Bingham and Ranker 2000; Lee et al. 2000; Fleishman et al. 2001; Wen and Hsiao 2001; Zawko et al. 2001).

Maze and Turkington (1996) showed a negative relationship between genetic variation of Trifolium repens and grassland age. They attributed this decrease in variation over time as the selective elimination of genotypes. In our study, testing for differences in genetic diversity among only three restored populations of different ages would lack statistical power. However, this study does provide baseline genetic diversity estimates for remnant and restored D. purpurea populations that could then be compared to future genetic sampling of these same populations. Understanding the distribution of genetic diver- sity in a temporal context will provide valuable insight into the evolutionary dynamics of plant populations and aid in the restoration and conservation of plant populations.

\section{Population Relationships}

Illinois populations were genetically different from Konza Prairie (Kansas) populations according to both allozyme and RAPD data, which is consistent with similar studies of the two dominant grasses (Andropogon gerardii and Sorghastrum nutans) of the tallgrass prairie (Gustafson et al. 1999; Gustafson 2000). Allozyme analysis was better able to resolve withinIllinois relationships than the RAPD analysis, with three paired associations reflecting geographic proximity. Genetic similarity among populations decreased as the geographic distance between populations increased. This result is important because it shows that the restored populations established with seed from sources within $80 \mathrm{~km}$ retained the local genotype. The continued use of locally collected seed for restoration projects will preserve the local genotype while maintaining the regional diversity.

\section{Competitive Abilities}

There was no discernible relationship between plant performance (height, biomass measures, number of inflorescences) and genetic diversity, although there was a significant seed source effect on competitiveness. The significant target plant effects and nonsignificant associate (neighbor) plant effects in the competition experiment indicate fundamental differences in competitiveness among source populations manifest regardless of the source of competing neighbors. Kansas plants, for example, were significantly shorter and produced less biomass (total, shoot, root, and inflorescences) than all four Illinois source populations regardless of which population the competing plant originated. This result is consistent with a similar study of a dominant grass species (A. gerardii) of the tallgrass prairie, in which competitive ability was related to the target plant population identity (Gustafson 2000). Despite limitations of the simple pairwise intraspecific competition experimental design (Gibson et al. 1999), this study identifies significant seed source (population) effects that could then be studied in more complex intra- and interspecific field competition experiments (Aarssen and Turkington 1985). Mixing of different source populations may occur through the introduction of nonlocal seed or through gene flow (seed or pollen dispersal) between adjacent but different populations (Gustafson et al 2001). Under such conditions, and following dis- 

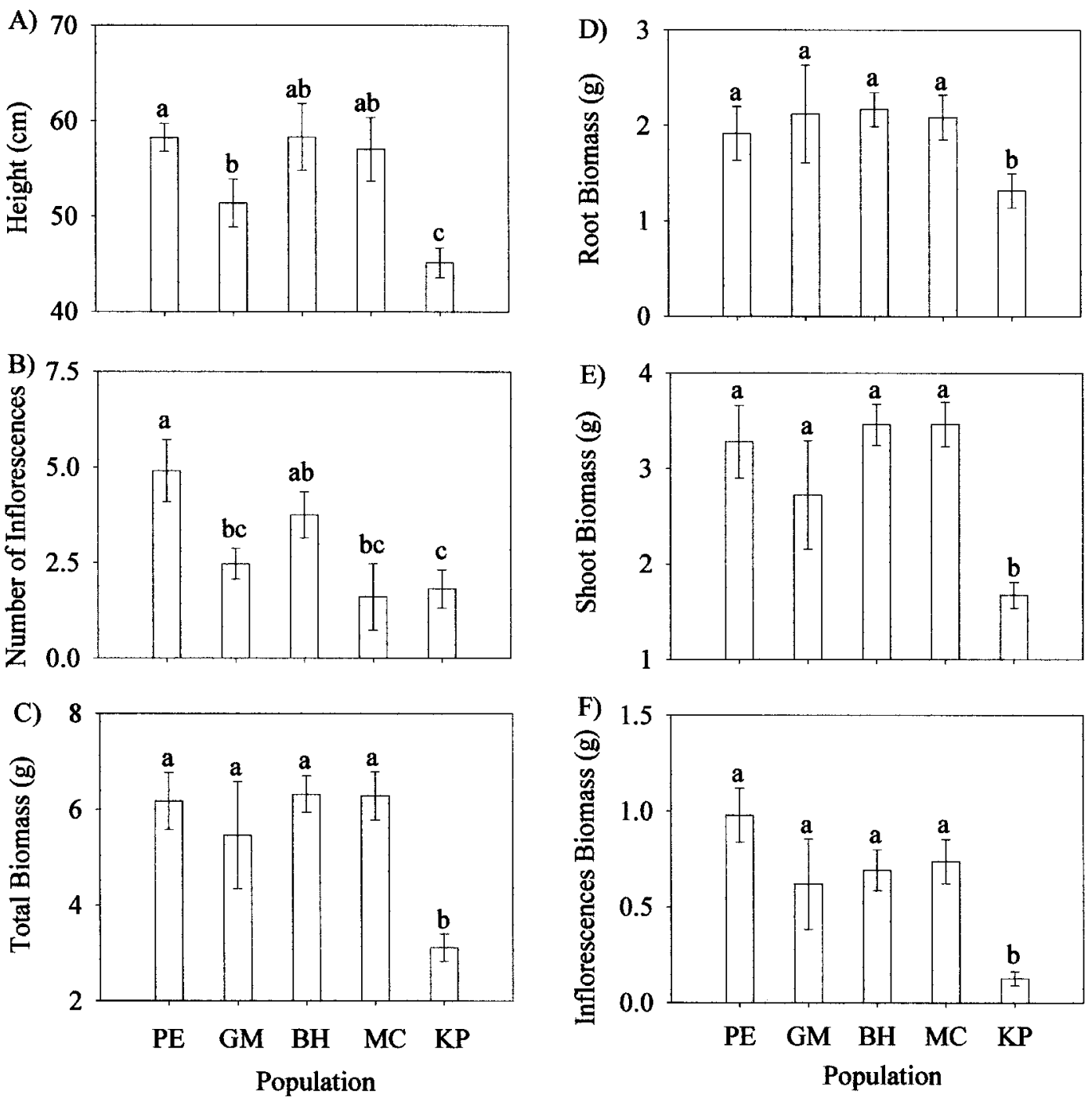

Fig. 2 Greenhouse diallel intraspecific competition experiment with Dalea purpurea from two remnant (Pellville [PE] and Gensburg-Markham $[G M]$ ) and two restored (Black Hawk $[B H]$ and Mason County $[M C])$ Illinois populations and Konza Prairie $(K P)$, Kansas. Values represent mean $( \pm 1 \mathrm{SE}$ ) for $(A)$ height, $(B)$ inflorescences, $(C)$ total biomass, $(D)$ root biomass, $(E)$ shoot biomass, and $(F)$ inflorescences biomass. Different letters above bars within the same graph represent significant differences $(P>0.05)$.

turbance-induced competitive release (Julita and Grace 2002), seedling competition is likely to be intense. Our study indicates that the outcome of seedling competition among different source populations under these conditions is likely to have significant ramifications for the genetic composition of these spatially structured populations at both the local and metapopulation level (sensu Freckleton and Watkinson 2002).

\section{Restoration Implications}

Most of the genetic variation was retained within populations, while genetic diversity was not related to size of the prairie. This suggests that small remnant populations can contribute much to the genetic diversity of restoration projects. The restored populations were established with seed from multiple sources within an $80-\mathrm{km}$ collection distance of the new site. The goals of restorationists using locally adapted seeds have been to preserve the local genotype and to increase the genetic diversity in the restored populations. Several authors have suggested that using locally collected seed will preserve the local genotype (Handel et al. 1994; Linhart 1995; Clewell and Rieger 1997; Gordon and Rice 1998) and that multiple seed sources will decrease the probability of low genetic diversity due to founder effects (Knapp and Dryer 1997; Montalvo et al. 1997; Lesica and Allendorf 1999; Fischer et al. 2000); however, ours is one of the first studies to provide empirical support for these theoretical predictions.

\section{Acknowledgments}

We would like to thank Brenda Casper, Jeff Klemens, and two anonymous reviewers for suggesting improvements to the manuscript. We would also like to acknowledge the laboratory 
assistance of Clay Crawford and Fawn Rogers. Site managers, Konza Prairie Biological Station, Joe Ely, and Dave Horvath provided seeds and access to and information about these tall- grass prairies. This study was funded by the Illinois Department of Natural Resources (Illinois Wildlife Preservation Fund) in a grant to D. L. Nickrent and D. J. Gustafson.

\section{Appendix}

Table A1

Isozyme Frequency Data of Dalea purpurea from Three Remnant and Three Restored Illinois Populations and Konza Prairie, Kansas, Collected in 1995

\begin{tabular}{|c|c|c|c|c|c|c|c|}
\hline \multirow[b]{2}{*}{$\begin{array}{l}\text { Locus and } \\
\text { allele }\end{array}$} & \multicolumn{3}{|c|}{ Remnant } & \multicolumn{3}{|c|}{ Restored } & \multirow{2}{*}{$\begin{array}{l}\text { Konza } \\
\text { Prairie, } \\
\text { Kansas }\end{array}$} \\
\hline & Pellville & $\begin{array}{l}\text { Grant } \\
\text { Creek }\end{array}$ & $\begin{array}{l}\text { Gensburg- } \\
\text { Markham }\end{array}$ & $\begin{array}{l}\text { Black } \\
\text { Hawk }\end{array}$ & $\begin{array}{l}\text { Mason } \\
\text { County }\end{array}$ & $\begin{array}{l}\text { Morton } \\
\text { Arboretum }\end{array}$ & \\
\hline \multicolumn{8}{|l|}{ AAT-2: } \\
\hline A & 1.00 & 1.00 & 1.00 & $0.92^{\mathrm{a}}$ & 1.00 & 1.00 & 1.00 \\
\hline B & 0.00 & 0.00 & 0.00 & $0.08^{\mathrm{b}}$ & 0.00 & 0.00 & 0.00 \\
\hline \multicolumn{8}{|l|}{ GPI-1: } \\
\hline A & 1.00 & 1.00 & 1.00 & 1.00 & 1.00 & 1.00 & 1.00 \\
\hline \multicolumn{8}{|l|}{ GPI-2: } \\
\hline A & 0.77 & 0.78 & 0.85 & 0.64 & 0.50 & 0.73 & 0.69 \\
\hline B & 0.19 & 0.20 & 0.15 & 0.19 & 0.35 & 0.18 & 0.15 \\
\hline $\mathrm{C}$ & 0.08 & 0.02 & 0.00 & 0.17 & 0.15 & 0.00 & 0.12 \\
\hline $\mathrm{D}$ & 0.00 & 0.00 & 0.00 & 0.00 & 0.00 & 0.10 & 0.04 \\
\hline \multicolumn{8}{|l|}{ 6-PGD-1: } \\
\hline A & 1.00 & 1.00 & 1.00 & 1.00 & 1.00 & 1.00 & 1.00 \\
\hline \multicolumn{8}{|l|}{ 6-PGD-2: } \\
\hline A & 1.00 & 1.00 & 1.00 & 1.00 & 1.00 & 1.00 & 1.00 \\
\hline \multicolumn{8}{|l|}{ TPI-1: } \\
\hline A & 1.00 & 1.00 & $0.88^{a}$ & 1.00 & 1.00 & $0.850^{\mathrm{a}}$ & 1.00 \\
\hline B & 0.00 & 0.00 & 0.13 & 0.00 & 0.00 & 0.15 & 0.00 \\
\hline \multicolumn{8}{|l|}{ TPI-2: } \\
\hline A & 1.00 & 0.96 & 0.93 & 0.97 & 0.95 & $0.925^{\mathrm{a}}$ & 0.96 \\
\hline B & 0.00 & 0.04 & 0.08 & 0.03 & 0.05 & 0.08 & 0.04 \\
\hline \multicolumn{8}{|l|}{ PGM-2: } \\
\hline A & 0.98 & 1.00 & 1.00 & 0.97 & 0.95 & 1.00 & 0.96 \\
\hline $\mathrm{B}$ & 0.02 & 0.00 & 0.00 & 0.03 & 0.05 & 0.00 & 0.00 \\
\hline C & 0.00 & 0.00 & 0.00 & 0.00 & 0.00 & 0.00 & $0.04^{\mathrm{b}}$ \\
\hline \multicolumn{8}{|l|}{ PGM-3: } \\
\hline A & 1.00 & 0.98 & 1.00 & 1.00 & 1.00 & 1.00 & 0.96 \\
\hline $\mathrm{B}$ & 0.00 & 0.00 & 0.00 & 0.00 & 0.00 & 0.00 & $0.04^{\mathrm{b}}$ \\
\hline $\mathrm{C}$ & 0.00 & $0.02^{\mathrm{b}}$ & 0.00 & 0.00 & 0.00 & 0.00 & 0.00 \\
\hline
\end{tabular}

${ }^{\text {a }}$ Allele frequencies at this locus were significantly different from Hardy-Weinberg equilibrium.

${ }^{\mathrm{b}}$ Allele that is unique to this population. 
Table A2

RAPD Frequency Data of Dalea purpurea from Three Remnant and Three Restored Illinois Populations and Konza Prairie, Kansas, Collected in 1995

\begin{tabular}{|c|c|c|c|c|c|c|c|}
\hline \multirow[b]{2}{*}{$\begin{array}{l}\text { Primer and } \\
\text { band }\end{array}$} & \multicolumn{3}{|c|}{ Remnant } & \multicolumn{3}{|c|}{ Restored } & \multirow{2}{*}{$\begin{array}{l}\text { Konza } \\
\text { Prairie, } \\
\text { Kansas }\end{array}$} \\
\hline & Pellville & $\begin{array}{l}\text { Grant } \\
\text { Creek }\end{array}$ & $\begin{array}{l}\text { Gensburg- } \\
\text { Markham }\end{array}$ & $\begin{array}{l}\text { Black } \\
\text { Hawk }\end{array}$ & $\begin{array}{l}\text { Mason } \\
\text { County }\end{array}$ & $\begin{array}{l}\text { Morton } \\
\text { Arboretum }\end{array}$ & \\
\hline \multicolumn{8}{|l|}{ A-04: } \\
\hline 1 & 0.154 & 0.050 & 0.050 & 0.174 & 0.286 & 0.000 & 0.000 \\
\hline 2 & 0.923 & 0.600 & 0.650 & 0.739 & 0.619 & 0.714 & 0.200 \\
\hline 3 & 0.077 & 0.100 & 0.150 & 0.261 & 0.286 & 0.000 & 0.000 \\
\hline 4 & 1.000 & 0.850 & 1.000 & 1.000 & 1.000 & 0.810 & 1.000 \\
\hline 5 & 0.885 & 0.300 & 0.800 & 0.957 & 1.000 & 0.095 & 0.133 \\
\hline \multicolumn{8}{|l|}{ B-07: } \\
\hline 1 & 0.080 & 0.333 & 0.263 & 0.045 & 0.000 & 0.350 & 0.385 \\
\hline 2 & 0.760 & 0.917 & 0.158 & 0.727 & 0.278 & 0.850 & 0.692 \\
\hline 3 & 0.680 & 0.083 & 0.316 & 0.636 & 0.556 & 0.150 & 0.154 \\
\hline \multicolumn{8}{|l|}{ B-12: } \\
\hline 1 & 0.615 & 0.353 & 0.471 & 0.762 & 0.600 & 0.429 & 0.167 \\
\hline 2 & 0.615 & 0.706 & 0.765 & 0.714 & 0.867 & 0.571 & 0.750 \\
\hline 3 & 0.654 & 0.647 & 0.706 & 0.762 & 0.800 & 0.857 & 0.750 \\
\hline 4 & 0.500 & 0.706 & 0.529 & 0.524 & 0.867 & 0.524 & 0.333 \\
\hline \multicolumn{8}{|l|}{ B-18: } \\
\hline 1 & 1.000 & 0.842 & 1.000 & 1.000 & 1.000 & 0.889 & 0.750 \\
\hline 2 & 0.192 & 0.421 & 0.526 & 0.143 & 0.286 & 0.500 & 0.167 \\
\hline 3 & 0.538 & 0.474 & 0.316 & 0.333 & 0.286 & 0.167 & 0.250 \\
\hline 4 & 0.962 & 0.842 & 0.947 & 0.952 & 1.000 & 0.833 & 0.583 \\
\hline 5 & 0.385 & 0.368 & 0.316 & 0.190 & 0.381 & 0.333 & 0.333 \\
\hline 6 & 0.192 & 0.211 & 0.263 & 0.381 & 0.143 & 0.389 & 0.250 \\
\hline 7 & 0.154 & 0.316 & 0.105 & 0.143 & 0.000 & 0.278 & 0.083 \\
\hline \multicolumn{8}{|l|}{ L-12: } \\
\hline 1 & 0.538 & 0.900 & 0.650 & 0.261 & 0.850 & 0.563 & 1.000 \\
\hline 2 & 1.000 & 0.600 & 0.800 & 1.000 & 0.900 & 0.750 & 0.722 \\
\hline 3 & 0.654 & 0.900 & 0.850 & 0.609 & 0.600 & 0.563 & 0.722 \\
\hline 4 & 0.077 & 0.150 & 0.050 & 0.043 & 0.050 & 0.125 & 0.000 \\
\hline \multicolumn{8}{|l|}{ N-13: } \\
\hline 1 & 0.269 & 0.300 & 0.050 & 0.261 & 0.238 & 0.050 & 0.250 \\
\hline 2 & 0.269 & 0.450 & 0.400 & 0.348 & 0.476 & 0.250 & 0.750 \\
\hline 3 & 0.577 & 0.250 & 0.800 & 0.391 & 0.333 & 0.300 & 0.313 \\
\hline 4 & 0.308 & 0.100 & 0.450 & 0.652 & 0.571 & 0.350 & 0.188 \\
\hline 5 & 0.808 & 0.250 & 0.250 & 0.522 & 0.286 & 0.550 & 0.250 \\
\hline
\end{tabular}

\section{Literature Cited}

Aarssen LW, R Turkington 1985 Biotic specialization between neighbouring genotypes in Lolium perenne and Trifolium repens from a permanent pasture. J Ecol 73:605-614.

Barrett SCH, JR Kohn 1991 Genetic and evolutionary consequences of small population size in plants: implications for conservation. Pages 3-30 in DA Falk, KE Holsinger, eds. Genetics and conservation of rare plants. Oxford University Press, Oxford.

Bingham RA, TA Ranker 2000 Genetic diversity in alpine and foothill populations of Campanula rotundifolia (Campanulaceae). Int J Plant Sci 161:403-411.

Clewell A, JP Rieger 1997 What practitioners need from restoration ecologists. Restor Ecol 5:350-354.

Collins SL, SM Glenn 1991 Importance of spatial and temporal dynamics in species regional abundance and distribution. Ecology 72 : 654-664.

Dawson IK, AH Simons, R Waugh, W Powell 1995 Diversity and genetic differentiation among subpopulations of Gliricidia sepium revealed by PCR-based assays. Heredity 75:10-18.
Dolan RW 1994 Patterns of isozyme variation in relation to population size, isolation, and phytogeographic history in royal catchfly (Silene regia; Caryophyllaceae). Am J Bot 81:965-972.

Ellstrand NC, ML Roose 1987 Patterns of genotypic diversity in clonal plant species. Am J Bot 74:123-131.

Etterson JR, RG Shaw 2001 Constraint to adaptive evolution in response to global warming. Science 294:151-154.

Fenster CB, MR Dudash 1994 Genetic considerations for plant population restoration and conservation. Pages 34-62 in ML Bowles, CJ Whelan, eds. Restoration of endangered species. Cambridge University Press, Cambridge.

Fischer M, M van Kleunen, B Schmidt 2000 Genetic Allee effects on performance, plasticity and development stability in a clonal plant. Ecol Lett 3:530-539.

Fleishman E, AE Launer, KR Switky, U Yandell, J Heywood, DD Murphy 2001 Rules and exceptions in conservation genetics: genetic assessment of the endangered plant Cordylanthus palmatus and its implications for management planning. Biol Conserv 98:45-53. 
Fore AF, SI Guttman 1992 Genetic structure after forest fragmentation: a landscape ecology perspective of Acer saccharum. Can J Bot 70:1659-1668.

1996 Spatial and temporal genetic structure of Asclepias verticillata (whorled milkweed) among prairie patches in a forested landscape. Can J Bot 74:1289-1297.

1999 Genetic structure of Helianthus occidentalis (Asteraceae) in a preserve with fragmented habitat. Am J Bot 86:988-995.

Franklin SB, DJ Gibson, PA Robertson, HT Pohlmann, JT Fralish 1995 Parallel analysis: a method for detecting significant principle components. J Veg Sci 6:99-106.

Freckleton RP, AR Watkinson 2002 Large-scale spatial dynamics of plants: metapopulations, regional ensembles and patchy populations. J Ecol 90:419-434.

Gibson DJ 1989 Hulbert's study of factors affecting botanical composition of tallgrass prairie. Pages 115-133 in T Bragg, J Stubbendieck, eds. Proceedings of the 11th North American prairie conference. University of Nebraska, Lincoln.

2002 Methods in comparative plant population ecology. Oxford University Press, Oxford.

Gibson DJ, J Connolly, DC Hartnett, JD Weidenhammer 1999 Designs for greenhouse studies of interactions between plants. J Ecol 87:1-16.

Gilpin ME, ME Soulé 1986 Minimum viable populations: processes of species extinction. Pages 19-34 in ME Soulé, ed. Conservation biology: the science of scarcity and diversity. Sinauer, Sunderland, Mass.

Gleason HA, A Cronquist 1991 Manual of vascular plants of northeastern United States and adjacent Canada. 2d ed. New York Botanical Garden, New York.

Gordon DR, KJ Rice 1998 Patterns of differentiation in wiregrass (Aristida beyrichiana): implications for restoration efforts. Restor Ecol 6:166-174.

Great Plains Flora Association, ed 1986 The flora of the Great Plains. University of Kansas Press, Lawrence.

Gustafson DJ 2000 Genetic and competition studies of Andropogon gerardii, Sorghastrum nutans and Dalea purpurea from remnant and restored tallgrass prairies. PhD diss. Southern Illinois University, Carbondale.

Gustafson DJ, DJ Gibson, DL Nickrent 1999 Randomly amplified polymorphic DNA (RAPD) variation among remnant big bluestem (Andropogon gerardii Vitman) populations from Arkansas' Grand Prairie. Mol Ecol 8:1693-1701.

2001 Characterizing three restored Andropogon gerardii Vitman (big bluestem) populations established with Illinois and Nebraska seed: established plants and their offspring. Pages 118-123 in NP Bernstein, LJ Ostrander, eds. Proceedings of the 17th North American prairie conference. Seeds for the future; roots of the past. North Iowa Area Community College, Mason City.

Hamrick JL 1989 Isozymes and the analysis of genetic structure in plant populations. Pages 87-105 in DE Soltis, PS Soltis, eds. Isozymes in plant biology. Dioscorides, Portland, Oreg.

Hamrick JL, MJ Godt 1989 Allozyme diversity in plant species. Pages 43-63 in AHD Brown, MT Clegg, AL Kahler, BS Weir, eds. Plant population genetics. Sinauer, Sunderland, Mass.

1997 Effects of life history traits on genetic diversity in plant species. Pages 102-118 in J Silvertown, M Franco, JL Harper, eds. Plant life histories: ecology, phylogeny, and evolution. Cambridge University Press, Cambridge.

Handel SN, GR Robinson, AJ Beattie 1994 Biodiversity resources for restoration ecology. Restor Ecol 2:230-241.

Hanski I 1991 Metapopulation dynamics: brief history and conceptual domain. Biol J Linn Soc 42:3-16.

Hartl DL, AG Clark 1997 Principles of population genetics. 3d ed. Sinauer, Sunderland, Mass.
Huff DR 1997 RAPD characterization of heterogeneous perennial ryegrass cultivars. Crop Sci 37:557-564.

Huff DR, R Peakall, PE Smouse 1993 RAPD variation within and among natural populations of outcrossing buffalograss (Buchloe dactyloides (nutt.) Engelm.). Theor Appl Genet 86:927-934.

Huff DR, JA Quinn, B Higgins, AJ Palazzo 1998 Random amplified polymorphic DNA (RAPD) variation among native little bluestem (Schizachyrium scoparium (Michx.) Nash) populations from sites of high and low fertility in forest and grassland biomes. Mol Ecol 7:1591-1597.

Husband BC, SCH Barrett 1996 A metapopulation perspective in plant population biology. J Ecol 84:461-469.

Jonsson BO, I Jonsdottir, N Cronberg 1996 Clonal diversity and allozyme variation in populations of the Arctic sedge Carex bigelowii (Cyperaceae). J Ecol 84:449-459.

Julita HM, JB Grace 2002 Effects of disturbance on germination and seedling establishment in a coastal prairie grassland: a test of the competitive release hypothesis. J Ecol 90:291-302.

Kephart SR 1990 Starch gel electrophoresis of plant isozymes: a comparative analysis of techniques. Am J Bot 77:693-712.

King LM, BA Schaal 1989 Ribosomal DNA variation and distribution in Rudbeckia missouriensis. Evolution 43:1117-1119.

Knapp AK, JM Briggs, DC Hartnett, SL Collins, eds 1998 Grassland dynamics: long-term ecological research in tallgrass prairie. Oxford University Press, Oxford.

Knapp EE, PG Connors 1999 Genetic consequences of a single-founder population bottleneck in Trifolium amoenum (Fabaceae). Am J Bot 86:124-130.

Knapp EE, AR Dryer 1997 When do genetic considerations require special approaches to ecological restoration? Pages $345-363$ in $\mathrm{P}$ Giedler, P Kareiva, eds. Conservation biology for the coming decade. Chapman \& Hall, New York.

Knapp EE, KJ Rice 1996 Genetic structure and gene flow in Elymus glaucus (blue wildrye): implications for native grassland restoration. Mol Ecol 4:1-10.

Lande R 1988 Genetic and demography in biological conservation. Science 241:1455-1460.

Lee HW, MG Chung, Y Suh, CW Park 2000 Allozyme variation and genetic relationships among species of Cimicfuga (Ranunculaceae) from Korea. Int J Plant Sci 161:413-423.

Lesica P, FW Allendorf 1999 Ecological genetics and the restoration of plant communities: mix or match. Restor Ecol 7:42-50.

Lewontin RC 1972 The apportionment of human diversity. Evol Biol 6:381-398.

Linhart YB 1995 Restoration, revegetation, and the importance of genetic and evolutionary perspectives. Pages 271-287 in BA Roundy, ED McArthur, JS Haley, DK Mann, eds. Proceedings: wildland shrub and arid land restoration symposium. Intermountain Research Station, Forest Service, USDA, Logan, Utah.

Linhart YB, MC Grant 1996 Evolutionary significance of local genetic differentiation in plants. Annu Rev Ecol Syst 27:237-277.

Longman RS, AA Cota, RR Holden, GC Fekken 1989 A regression equation for the parallel analysis criterion in principle components analysis: mean and 95th percentile eigenvalues. Multivar Behav Res 24:59-69.

Maze J, R Turkington 1996 The influence of pasture age, plant diversity, and genotype on intraspecific diversity of Trifolium repens (white clover). Can J Bot 74:1189-1192.

McCune B 1995 Multivariate analyses of ecological data. 2d ed. MJM Software Design, Gleneden Beach, Oreg.

McFall D, ed 1991 A directory of Illinois nature preserves. State of Illinois, Department of Conservation, Division of Natural Heritage, Springfield.

Miller MP 1997 Tools for population genetic analyses (TFPGA). Available at http://bioweb.usu.edu/mpmbio/tfpga.htm.

Montalvo AM, SL Williams, KJ Rice, CC Buchamann, SN Handel, 
GP Nabhan, R Primack, RH Robichaux 1997 Restoration biology: a population biology perspective. Restor Ecol 5:277-290.

Newman D, D Pilson 1997 Increased probability of extinction due to decreased genetic effective population size: experimental populations of Clarkia pulchella. Evolution 51:354-362.

Ridgeway GJ, SW Sherburne, RD Lewis 1970 Polymorphisms in the esterases of Atlantic herring. Trans Am Fish Soc 99:147-151.

Robertson KR 2001 Planning with plants in Illinois. Pages 28-45 in JB Phipps, PM Catling, eds. Bioconservation and systematics. Canadian Botanical Association, Ontario.

Robertson KR, RC Anderson, MW Schwartz 1997 The tallgrass prairie mosaic. Pages 55-87 in MW Schwartz, ed. Conservation in highly fragmented landscapes. Chapman \& Hall, New York.

Robertson KR, MW Schwartz 1994 Prairies, changing Illinois environment: critical trends. Vol 3. Ecological resources (ILENR/REEA-94/05). Illinois Department of Energy and Natural Resources, Champaign.

Saccheri I, M Kuussaari, M Kankare, P Vikman, W Fortelius, I Hanski 1998 Inbreeding and extinction in a butterfly metapopulation. Nature 392:491-494.

SAS Institute 1989 SAS/STAT user's guide. 4th ed. SAS Institute, Cary, N.C.

Swofford DL, RB Selander 1981 BIOSYS-1: a FORTRAN program for comprehensive analysis of electrophoretic data in population genetics and systematics. J Hered 72:281-283.
Templeton AR, K Shaw, E Routman, SK Davis 1990 The genetic consequences of habitat fragmentation. Ann Mo Bot Gard 77:13-27.

Turkington R 1994 Effect of propagule source on competitive ability of pasture grass: spatial dynamics of six grasses in simulated swards. Can J Bot 72:111-121.

Wen CS, JY Hsiao 2001 Altitudinal genetic differentiation and diversity of Taiwan lily (Lilium longiflorum var. formosanum; Liliaceae) using RAPD markers and morphological characters. Int J Plant Sci 162:287-295.

Wendel NF, JF Weeden 1989 Visualization and interpretation of plant isozymes. Pages 5-45 in DE Soltis, PS Soltis, eds. Isozymes in plant biology. Dioscorides, Portland, Oreg.

White J 1978 Illinois natural areas inventory. Vol 1. Survey methods and results. Illinois Natural History Survey, Urbana.

Wilkinson L 1996 SYSTAT: the system for statistics. 6th ed. SYSTAT, Evanston, Ill.

Williamson PS, CR Werth 1999 Levels and patterns of genetic variation in the endangered species Abronia macrocarpa (Nyctaginaceae). Am J Bot 86:293-301.

Wiltshire B 1991 Assessment of genetic diversity in Astragalus tennesseensis and the federal endangered Dalea foliosa. MS thesis. Southern Illinois University, Carbondale.

Zawko G, SL Krauss, KW Dixon, K Sivasithamparam 2001 Conservation genetics of the rare and endangered Leucopogon obtectus (Ericaceae). Mol Ecol 10:2389-2396. 